\title{
'Florida Elyana' Strawberry
}

\author{
Craig K. Chandler ${ }^{1}$, Bielinski M. Santos, Natalia A. Peres, \\ and Celine Jouquand \\ Gulf Coast Research and Education Center, University of Florida, 14625 CR \\ 672, Wimauma, FL 33598
}

\section{Anne Plotto \\ USDA-ARS, Citrus and Subtropical Products Laboratory, 600 Avenue S, NW, Winter Haven, FL 33881}

Additional index words. Fragaria $\times a n a n a s s a$, fruit breeding, small fruit germplasm

There are two predominant strawberry (Fragaria xananassa Duch.) production systems throughout the world: open-field cultivation and production under protective structures (e.g., high tunnels and greenhouses). In California and Florida, strawberry is produced predominantly under open-field conditions, whereas in Japan and in parts of Europe such as Spain, The Netherlands, and Germany, the latter system is widely used. Because of the environmental differences between these two systems, there is a necessity for breeding cultivars that could be adapted to each specific situation. 'Florida Elyana' is the first Florida-bred cultivar designed for tunnel and greenhouse production. It is a short-day plant and produces flavorful fruit. 'Florida Elyana' produces larger fruit than 'Strawberry Festival', which is the predominant cultivar in Florida and it holds a large market share in Spain, Morocco, and Egypt.

\section{Origin}

'Florida Elyana' strawberry (Fragaria ×ananassa Duch.) originated from a 2000 cross between FL 96-114 and FL 95-200 (Fig. 1). FL 96-114 resulted from a cross between 'Sweet Charlie', a 1992 University of Florida release (Chandler et al., 1997), and 'Cuesta' (U.S. Plant Patent 8,662), a Univ. of California cultivar released in the early 1990s. FL 95-200 is a result of a cross of the lines FL 93-46 and FL 93-66, both of which have a number of cultivars in its complex pedigree, including 'Rosa Linda' and 'Pajaro'.

Based on the desirable appearance and firmness of 'Florida Elyana' fruit, it was included in randomized complete block trials at the Gulf Coast Research and Education Center of the University of Florida at Dover and Balm, FL, respectively, during the 2004 2005 and 2006-2007 seasons. Ripe fruit were harvested, graded, counted, and weighed twice a week from December through March. For postharvest quality analysis, sensory

Received for publication 30 Mar. 2009. Accepted for publication 4 Aug. 2009.

${ }^{1}$ To whom reprint requests should be addressed; e-mail ckc@ufl.edu. panels were conducted at the Gulf Coast Research and Education Center two times during 2006 and three times during 2007. Participants were employees from and visitors to the center willing to consume strawberries. Six or seven tasting stations, coded A through $\mathrm{G}$ corresponding to the selection codes, were arranged around a large central laboratory table. At least 50 untrained panelists participated in these panels and rated fruit for appearance, texture, and flavor. Panelist ages ranged from younger than 26 to older than 65 years old with the majority of panelists between 36 and 55 years old. Approximately half of all panelists were repeat tasters. Strawberries were presented in bulk on a $23-\mathrm{cm}$ diameter plate at each station. Unsalted crackers and spring water were provided for cleansing the palate between samples. Panelists were asked to taste the berries following the codes written on their ballot sheets and answer the questions on the ballots. Presentation was randomized across panelists and serving order was balanced so that each sample was tested in each station. Panelists were asked to rate samples for appearance, flavor, and texture on a 9-point hedonic scale $(1=$ dislike extremely, $5=$ neither like nor dislike, $9=$ like extremely). A line for comments was provided after each question. Fresh fruit was transported to the Citrus and Subtropical Products Laboratory, Agricultural Research Service, U.S. Department of Agriculture in Winter Haven, FL, where they were analyzed for soluble solids content (SSC) and titratable acidity (TA). Fruit were analyzed for surface color using a colorimeter (Konica Minolta Sensing, Inc., Osaka, Japan) and firmness using a penetrometer (Model 4411; Instron, Canton, MA).

\section{Description}

'Florida Elyana' is a short-day cultivar. It is smaller and a lower-stature plant than 'Strawberry Festival' (Chandler et al., 2000). This habit, along with fruit that are attached to long pedicels, makes the fruit easy to harvest (Fig. 2). 'Florida Elyana' produces larger fruit than 'Strawberry Festival'. It has a mean fruit weight in west central Florida of between 24 and $27 \mathrm{~g}$ compared with between 17 and $21 \mathrm{~g}$ for 'Strawberry Festival' (Tables 1 and 2). Fruit are mostly medium conic to wedge-shaped with the wedge-shaped fruit often showing a longitudinal crease on the broad sides of the fruit. (Fig. 3). 'Florida Elyana' fruit are quite susceptible to surface cracking, which is the result of exposure to free moisture. Thus, we are not recommending this cultivar for open-field culture where there is a high likelihood of multiple rain or dew events during the fruiting season. External fruit color is a bright red, and internal color is carmine pink. The calyx is generally medium in size and attractive. Fruit texture is firm (Table 3) and the flavor is usually sweet with a pleasant aroma. The soluble solid content of 'Florida Elyana' fruit is as high as or higher than that of 'Strawberry Festival' (Table 4), and its SSC/TA ratio is consistently higher than that of 'Strawberry Festival'.

\section{Performance}

'Florida Elyana' is as productive as 'Strawberry Festival' in December and January, but not as productive later in the season (Tables 1 and 2). This could be because 'Florida Elyana' plants stay relatively small throughout the season, whereas 'Strawberry Festival' plants are more vigorous in terms of producing new branch crowns. However, in a high tunnel trial at the Gulf Coast Research and Education Center in the 2006-2007 season, total season yield for 'Florida Elyana' was not significantly different from that of 'Strawberry Festival' (Santos et al., 2008). Growers may be able to increase the productivity of 'Florida Elyana' on a per-unit 


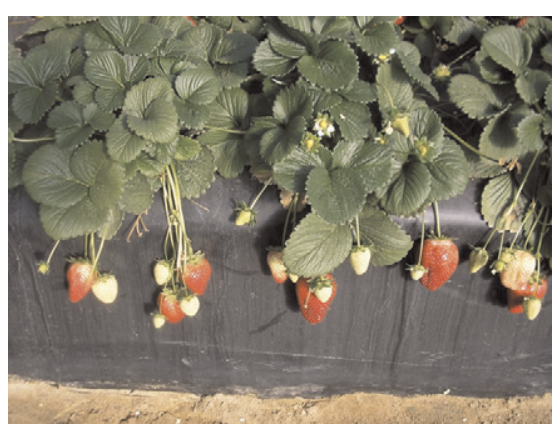

Fig. 2. Plants of 'Florida Elyana' strawberry in Spain.

Table 1. Performance of strawberry cultivars at Dover, FL, during the 2004-2005 season in open-field culture. $^{2}$

\begin{tabular}{lcccccc}
\hline & \multicolumn{5}{c}{ Marketable fruit yield } \\
\cline { 2 - 5 } Cultivars & December & January & February & March & Total & \\
\cline { 2 - 5 } & & & $(\mathrm{g} / \mathrm{plant})$ & & \\
\hline Florida Elyana & $76 \mathrm{a}^{\mathrm{y}}$ & $108 \mathrm{~b}$ & $178 \mathrm{a}$ & $353 \mathrm{a}$ & $715 \mathrm{a}$ & $27.1 \mathrm{a}$ \\
Strawberry Festival & $37 \mathrm{~b}$ & $144 \mathrm{a}$ & $155 \mathrm{~b}$ & $592 \mathrm{a}$ & $928 \mathrm{~b}$ & $20.6 \mathrm{~b}$ \\
Significance $(P<0.05)$ & $*$ & $*$ & $*$ & NS & $*$ & $*$ \\
\hline
\end{tabular}

${ }^{\mathrm{z}}$ Mean fruit weight was determined by dividing total marketable fruit yield per plot by total marketable fruit number per plot.

${ }^{\mathrm{y}}$ Means based on four replications of 10 plants each. Mean separation within columns by Fisher's protected least significant difference test $(P<0.05)$.

NS $=$ nonsignificant.

Table 2. Performance of strawberry cultivars at Dover, FL, during the 2006-2007 season in high-tunnel culture. $^{z}$

\begin{tabular}{lcccccc}
\hline & \multicolumn{5}{c}{ Marketable fruit yield } \\
\cline { 2 - 6 } Cultivars & December & January & February & March & Total & \\
\cline { 2 - 6 } & \multicolumn{5}{c}{ (g/plant) } & \\
\hline Florida Elyana & $46 \mathrm{a}^{\mathrm{y}}$ & $99 \mathrm{a}$ & $159 \mathrm{~b}$ & $322 \mathrm{~b}$ & $626 \mathrm{~b}$ & $24.4 \mathrm{a}$ \\
Strawberry Festival & $65 \mathrm{a}$ & $94 \mathrm{a}$ & $218 \mathrm{a}$ & $459 \mathrm{a}$ & $836 \mathrm{a}$ & $17.3 \mathrm{~b}$ \\
Significance $(P<0.05)$ & $\mathrm{NS}$ & NS & $*$ & $*$ & $*$ & $*$ \\
\hline
\end{tabular}

${ }^{\mathrm{z}}$ Mean fruit weight was determined by dividing total marketable fruit yield per plot by total marketable fruit number per plot.

${ }^{\mathrm{y}}$ Means based on four replications of 10 plants each. Mean separation within columns by Fisher's protected least significant difference test $(P<0.05)$.

NS $=$ nonsignificant.

Table 3. Mean acceptance scores (9-point hedonic scale) for appearance, texture, and flavor of 'Florida Elyana' and 'Strawberry Festival' strawberry evaluated over two harvest seasons.

\begin{tabular}{lccccc}
\hline & Feb. 2006 & Mar. 2006 & Jan. 2007 & Feb. 2007 & Mar. 2007 \\
\hline Appearance & & & & & \\
$\quad$ Florida Elyana & $6.6 \mathrm{~b}^{2}$ & $7.5 \mathrm{a}$ & $5.9 \mathrm{a}$ & $6.4 \mathrm{~b}$ & $6.0 \mathrm{a}$ \\
$\quad$ Strawberry Festival & $7.8 \mathrm{a}$ & $6.8 \mathrm{~b}$ & $6.2 \mathrm{a}$ & $7.2 \mathrm{a}$ & $6.3 \mathrm{a}$ \\
Texture & & & & & \\
$\quad$ Florida Elyana & $7.4 \mathrm{a}$ & $7.1 \mathrm{a}$ & $6.9 \mathrm{a}$ & $6.9 \mathrm{a}$ & $6.2 \mathrm{a}$ \\
$\quad$ Strawberry Festival & $7.5 \mathrm{a}$ & $6.6 \mathrm{a}$ & $6.4 \mathrm{a}$ & $6.8 \mathrm{a}$ & $6.2 \mathrm{a}$ \\
Flavor & & & & & \\
$\quad$ Florida Elyana & $7.3 \mathrm{a}$ & $7.0 \mathrm{a}$ & $6.5 \mathrm{a}$ & $6.7 \mathrm{a}$ & $6.2 \mathrm{a}$ \\
$\quad$ Strawberry Festival & $7.3 \mathrm{a}$ & $6.2 \mathrm{~b}$ & $5.9 \mathrm{~b}$ & $6.9 \mathrm{a}$ & $5.1 \mathrm{~b}$ \\
\hline
\end{tabular}

${ }^{\mathrm{z}}$ Mean separation within columns by Fisher's protected least significant difference test $(P \leq 0.05)$.

Table 4. Soluble solid content (SSC) and titratable acidity (TA) of 'Florida Elyana' and 'Strawberry Festival' strawberry evaluated over two harvest seasons.

\begin{tabular}{lccccc}
\hline & Feb. 2006 & Mar. 2006 & Jan. 2007 & Feb. 2007 & Mar. 2007 \\
\hline SSC ( ${ }^{\circ}$ Brix) & & & & & \\
$\quad$ Florida Elyana & $10.2 \mathrm{a}^{\mathrm{z}}$ & $8.2 \mathrm{a}$ & $0.7 \mathrm{a}$ & $9.6 \mathrm{a}$ & $7.3 \mathrm{a}$ \\
$\quad$ Strawberry Festival & $7.5 \mathrm{~b}$ & $7.5 \mathrm{~b}$ & $6.9 \mathrm{~b}$ & $9.8 \mathrm{a}$ & $6.2 \mathrm{~b}$ \\
TA (\%) & & & & & \\
$\quad$ Florida Elyana & $0.82 \mathrm{a}$ & $0.58 \mathrm{a}$ & $0.78 \mathrm{~b}$ & $0.71 \mathrm{~b}$ & $0.69 \mathrm{a}$ \\
$\quad$ Strawberry Festival & $0.75 \mathrm{~b}$ & $0.63 \mathrm{a}$ & $0.91 \mathrm{a}$ & $0.87 \mathrm{a}$ & $0.73 \mathrm{a}$ \\
\hline
\end{tabular}

${ }^{\mathrm{z}}$ Mean separation within columns by Fisher's protected least significant difference test $(P \leq 0.05)$. area basis by planting this cultivar at a higher than standard density. 'Florida Elyana' is moderately resistant to the two most serious disease problems on strawberry in Florida: Botrytis fruit rot [caused by Botrytis cinerea (de Bary) Whetzel] and anthracnose fruit rot (caused by Colletotrichum acutatum Simm.). In an unsprayed trial during the 2007-2008 season, only 3\% of the 'Florida Elyana' fruit harvested from mid-February to mid-March showed symptoms of anthracnose fruit rot compared with $53 \%$ for 'Treasure', the susceptible control (N. Peres, unpublished data). 'Florida Elyana' also appears to have resistance to wilts, which are most likely caused by $C$. gloeosporioides (Penz.) Penz. and Sacc. and Phytophthora spp. (C.K. Chandler, personal observations). In summary, 'Florida Elyana' is recommended for winter and spring production areas where strawberries are grown in tunnels or greenhouses.

\section{Availability}

Information on nurseries licensed to propagate 'Florida Elyana' can be obtained from the Florida Foundation Seed Producers, Inc. (http://ffsp.net).

\section{Literature Cited}

Chandler, C.K., E.E. Albregts, C.M. Howard, and J.K. Brecht. 1997. 'Sweet Charlie' strawberry. HortScience 32:1132-1133.

Chandler, C.K., D.E. Legard, D.D. Dunigan, T.E. Crocker, and C.A. Sims. 2000. 'Strawberry Festival' strawberry. HortScience 35:13661367.

Santos, B.M., C.K. Chandler, S.M. Olson, and T.W. Olczyk. 2008. Performance of strawberry cultivars in Florida. Proc. Fla. State Hort. Soc. 120:155-156. 